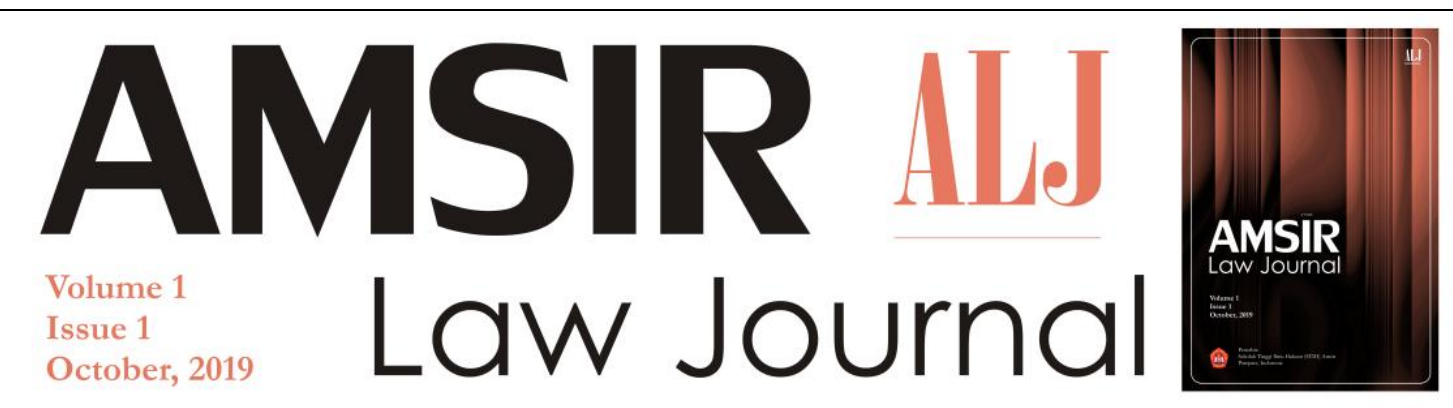

e-issn:

Nationally Accredited Journal, Decree No. ........................

This work is licensed under a Creative Commons Attribution 4.0 International License.

\title{
Journalist Competence in Applying the Presumption of Innocence Principle on Press Release
}

\section{Mustawa Mustawa ${ }^{1}$}

\begin{tabular}{l} 
ARTICLE INFO \\
\hline Keywords: \\
Journalist Competence; \\
Presumption of Innocence \\
Principles; Press Coverage. \\
How to cite: \\
Mustawa Mustawa \\
(2019). \\
Amsir Law Journal, 1(1), \\
36-42 \\
DOI: \\
............. /alj.xxxxx
\end{tabular}

\begin{abstract}
A journalist competence as intended in the Press Council Regulation is interpreted as knowledge capability without affirmation for journalists who have knowledge of certain scientific disciplines. The meaning is all journalists from any discipline may be recognized as journalists who have the competence to apply the presumption of innocence in reporting. This arrangement in journalistic practice, the press often appears' 'judgmental' in the news because the use of the terms is often interpreted the same, even though the law holds very different meanings, such as the suspect is written as the perpetrator, released is written as free, not accepted is written as rejected, sentenced to trial is written as the judge free it. To prevent the violation of the presumption of innocence principle in reporting, the regulation of journalists' competencies must be emphasized from intellectual abilities and general knowledge to legal knowledge. The affirmation is directly correlated with the news object which is in the realm of law as a function of the press that is obliged to respect the presumption of innocence principle.
\end{abstract}

Copyright (C) 2019 ALJ. All rights reserved.

\section{Introduction}

Journalist competence is an urgent matter in applying the presumption of innocence principle in reporting, especially the level of journalist's legal knowledge in understanding the articles governing the Journalistic Code of Ethics, the Press Law, the Libel according to the Criminal Code. Journalists who are not supported by legal knowledge may or may not be able to know all aspects of the law or all laws and regulations regarding the press. As workers in the press profession, the journalists are notably required to know the laws which govern their lives, in this case, Law Number 40 of 1999 concerning the Press, the Journalistic Code

Fakultas Hukum Universitas Bosowa, Indonesia.E-mail: mustawanur2@gmail.com 
of Ethics and articles relating to the Libel in the Criminal Code. Journalist competence is related to intellectual abilities and general knowledge. In the competence of journalist, an understanding of the freedom communication nation and democratic state is essential. Journalist competencies include the ability to understand the ethics and law of the press, conception of the news, preparation and editing of news, and language. The last thing also involves the skills to conduct the comprehensions, such as technical skills as a professional journalist, namely: finding, obtaining, storing, possessing, processing, making and broadcasting news. $^{2}$

Respecting these principles, news writing standards based on the provisions of Article 3 of the Journalistic Code of Ethics are as follows: ${ }^{3}$ Indonesian journalists always test information, report in a balanced manner, separate facts and judgmental opinions, and apply the presumption of innocence principle.

The provisions of Article 3 above, if qualified as an act of the journalist profession in writing legal news, then there were 4 (four) elements that must be fulfilled, namely: testing information; balanced; separating judgmental facts and opinions; and applying the presumption of innocence.

According to the author, the fourth element, which is to apply the presumption of innocence principle, does not need to be an element which must be fulfilled as a qualification for journalists' professional acts in writing legal news because the other three elements are an inseparable part as a system for implementing the presumption of innocence. Strictly speaking, if one of the elements, whether the first, second, or third element is not fulfilled, it could be declared as having fulfilled the element of violating the presumption of innocence through legal news writing.

The author should continue to apply the presumption of innocence principle as a standard setting for writing legal news with the following elements: first, testing information; second, being balanced; third, separating the facts and judgmental opinions. However, the researcher continued, the three elements were not sufficient to apply the presumption of innocence because the level of effectiveness of legal news writing standards was also determined which was also determined by how high the level of legal knowledge of journalists in applying the presumption of innocence to news writing rules in Article 3 of the Code Journalistic Ethics. The higher level of legal knowledge of journalists, the greater news will be written which prevent violations of the presumption of innocence. On that basis, researchers formulated the concept of journalist competence with news writing standards which apply the presumption of innocence to include 4 (four) elements that must be fulfilled. The four elements are as follows: (1) Testing Information; (2) Being Balanced; (3) and Judging Opinion.

\section{Method}

This study used an normative juridical approach, which is a method or procedure used to solve problems by first examining existing secondary data, the research was methods were used with prescriptive analytical. ${ }^{4}$

\footnotetext{
Attachment Peraturan Dewan Pers No. 01/Peraturan-DP/X/2018 tentang Standar Kompetensi Wartawan, p. 5.

Attachment Surat Keputusan Dewan Pers No. 03/SK-DP/III/2006, 24 March 2006.

Soemitro, R.H. (1998). Metodologi Penelitian Hukum. Jakarta: Ghalia Indonesia, p. 10.
} 


\section{Discussion}

\subsection{Test Information}

Test information ${ }^{5}$ one of the elements which becomes the standard for writing news in applying the presumption of innocence as an instrument to ensure the truth of the information to be conveyed to the public. The instrument is the first element in the interpretation of Article $3^{6}$ of the Journalistic Code of Ethics.

The starting point from the case, all information which received by journalists must not necessarily be reported before checking and rechecking for proving a source of information is a fact.

Edy Susanto, Muhammad Taufik Makarao, Hamid Syamsuddin stressed which journalists must have very high caution in carrying out their work, given the wide-ranging impact caused by the news they produced. Caution is started from carefulness of the spelling of the name, number, date, and age and self-discipline to always check again the information and facts which is found. Additionally, accuracy also means the truth in giving a general impression, the truth in the news point of view achieved by presenting the details of facts and by the pressure exerted on the facts. Readers are usually very concerned about this accuracy. The case is largely determined by the accuracy of the news as a consequence of the reporter carefulness in making the news. ${ }^{7}$

In "official interpretation" accurately explained which is believed that being true is according to the objective situation when the event occurred. This does not mean as long as there is a trust, it means that the facts are accurate. To arrive at the conclusion, a fact can be objectively trusted when it is true and has certain conditions. Wina Armada Sukardi mentioned, as follows: ${ }^{8}$

1. Journalists have to do the verification or maximum testing beforehand to the parties or related problems, whether the facts were really not wrong at that time.

2. Journalists must test this fact with common sense. The process of making news itself must be with precision, conscientiousness and accuracy.

3. Journalists must put the facts contextually. Although both the facts are true, if misplaced in the actual context can produce the meaning which is not only different but also contradictory. Therefore, facts must be placed in the right context.

Thus, journalists stand outside of the parties who have problems or interests. Also, the journalists cannot take any sides with one or having an interest in something or with a particular person or party. Therefore, the working principles of journalist are check and recheck. If a journalist gets information about something which is contrary to something else then it is not what the journalist writes and reports through the media but must check or check the "truth" of that information, especially if the information is related to other parties in the dispute context or conflict of interest. The presentation of information is also purely

Article 3 (a) Keputusan Dewan Pers No. 03/SK-DP/III/2006 tentang Kode Etik Jurnalistik

The Journalistic Code of Ethics, as a guideline in carrying out the profession, KEJ aims that journalists are responsible for carrying out their profession, namely seeking and presenting information. Thus, the KEJ is the moral and ethical foundation of the profession as an operational guideline in maintaining public trust and upholding integrity and professionalism. See Sugiharto, R. Toto. (2019). Panduan Menjadi Jurnalis Profesional. Yogyakarta: Araska, p. 205-206.

Susanto, Edy, etc. (2014). Hukum Pers di Indonesia. Jakarta: Rineka Cipta, p. 89.

8 Sukardi, Wina Armada. (2012). Kajian Tuntas 350 Tanya Jawab UU Pers dan Kode Etik Jurnalistik. Jakarta: Press Council, p. $147-148$. 
from what is obtained from sources or events, and not added any kind of intention from the journalist himself/herself orhis/her the imagination. ${ }^{9}$

\subsection{Balanced}

Even though the element of testing information has been fulfilled in writing legal news, it also cannot be considered feasible to report if the balanced element is not fulfilled. Balanced ${ }^{10}$ is the second element in applying the presumption of innocence principle by giving space or time for reporting to each party proportionally.

In journalistic terminology simply, the word balanced is fair, impartial, and neutral. Any media crews (journalists) who will present the news are required to uphold this principle. The goal is to respect the right of people to obtain correct information. In addition, the community also has the right to get a good education from the media. ${ }^{11}$

Presenting information not only from one side or one party, except for news or information that is a press release issued by a formal institution. However, in some cases the press release also requires journalists to be more creative by confirming or clarifying, both to explore the release material in order to get a new angle, as well as to complete the release material or issues raised in the release material. ${ }^{12}$

Examples of unbalanced news, for example, appear in the case of Ustaz Solmed's "feud" with the Hong Kong TKI organization, called Thoriqul Jannah which had become a "trending topic" among Hong Kong migrant workers and infotainment in Indonesian television. As reported "Kapan Lagi" with the title "Ustaz Solmed is assessed as Da'i 'Matre", a local Hong Kong-language newspaper in Indonesian, took down the essence of the news which said that Ust. Solmed unilaterally canceled the lecture schedule in Hong Kong, he requested an increase in lecture rates from IDR 6 million to IDR 10 million, also a share of ticket sales and "traveling turban", and he asked for starred lodging and private pickup cars while in Hong Kong. The news was unbalanced because it only contained the votes of one party. There were no objections, clarifications, or comments contained in the news from Ust. Solmed. Only in the next news, entitled "Ustaz Solmed Speak Up ...", the news was balanced, fulfilling journalistic code of ethics. News of the local Hong Kong newspaper quoted "Kapan Lagi", if indeed does not contain clarification from Ust. Solmed including the news those were unbalanced and violated the ethics code of journalistic. As a result of the unbalanced news, the media in Indonesia interviewed Ust. Solmed and wrote a news which was unbalanced. Many media only contain Ust Solmed statements without including the votes of the Hong Kong TKI. Ust. Solmed said that Hong Kong TKI were doing teaching or lecturing business, claimed not to ask for payment, to pay for food and to drink in Hong Kong. ${ }^{13}$

In reporting and disseminating information, there must be a balance of news. The purpose of this balance is to place a balanced news/information between facts and opinions, without a verdict and applying the principles of justice. The cover of both sides stems from the understanding that what is conveyed through the news must be understood about the meaning of the responsibility. This means that both sides cover encourages an appropriate form of responsibility from the media, related to the news which is disseminated. This

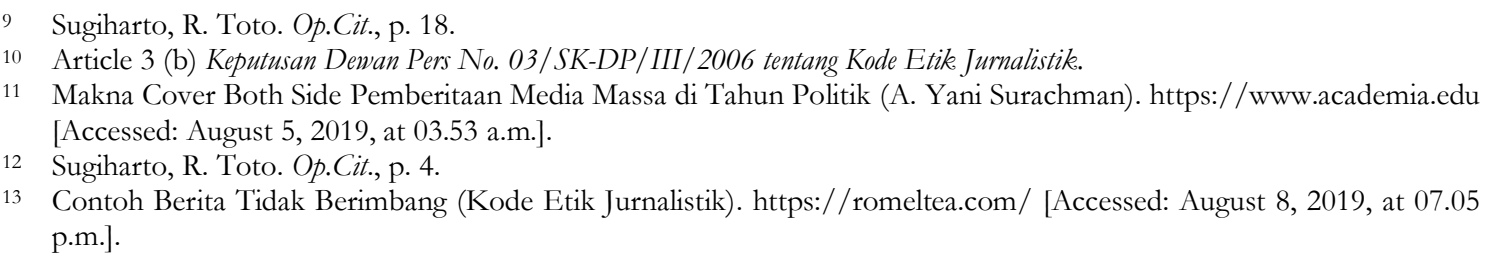


responsibility refers more to the substance of information, which demands a balance between the parties concerned in that substance. This concept which leads to balance, media balance or news balance or equivalent conception focuses on the presence of balanced news/information. The balance is also then synonymous with the justice of the news which requires consistency. ${ }^{14}$

Starting from the explanation above, the mistakes in reporting are a threat to freedom of the press, ranging from the style of gangster-ism to a more polite way of suing in court. In any position, journalists must understand the news writing standards, one of which is emphasizing the importance of balanced news to each party in order to be proportionately informed. Various cases that stick out are caused by unbalanced news (cover both sides), clearly mentioning the subject and actions furthermore the news becomes sentimental.

\subsection{Judging Opinion}

Journalists do not mix facts and judgmental opinion, as stated in Article 3 of the Journalistic Code of Ethics. In the stated, the judgmental opinion is the personal opinion of the journalist. This is different from interpretive opinion, which is opinion in the form of journalist's interpretation of facts. So, in writing news, journalists must write or present only facts, facts of events, without adding opinions. If the news is added by journalists' opinions, it is not allowed to be judgmental or subjective opinions, but must be interpretive opinions that form based on journalists' interpretation of facts. Apart from the code of ethics, writing opinions for news is also risky, especially if the opinions of journalists anger certain parties. For example, reporters write "... the judge's verdict is too light ...", then the family of the convicted person can "throw tantrums" to reporters or the media that contain the news. ${ }^{15}$

Even though the presumption of innocence principle in the press is forbidden produce judgmental news but this does not automatically mean that the press may include the complete identities of all people in press releases. Both the law and the Journalistic Ethics Code present the restrictions on the press in revealing people's identities. The Vienna Armada mentions the following: ${ }^{16}$

1. The press is forbidden to mention the identity of children clearly either name the children as perpetrators, or are suspected of being perpetrators of crime.

2. The press is prohibited from mentioning the identity of children in cases involving decency.

3. The press is forbidden to mention the identity of decency victims either children or non-children.

Daily facts regarding the reporting of events allegedly involving violations of the law, the general public who do not understand ethics in the practice of the press legal and judicial matters will certainly be confused if reading various media whose attitudes are not the same in naming the names and identities of violators in the news crime story or trial. Some newspapers and magazines only mention the abbreviation or initial name from the identity of the perpetrator but other newspapers and magazines openly write his name in full. Respecting the presumption of innocence principle, it means that journalists are obliged to protect the suspect/defendant of a criminal offense by not mentioning the name and identity which states the culprit's guilt and the decision has obtained permanent legal force. The press

14 Mengenal Prinsip Cover Both Side (Setyo Pamungkas). https://wordpress.com [Accessed: September 9, 2019, at 08.20 p.m.].

15 Perbedaan Fakta dan Opini. https://www.romelteamedia.com [Accessed: August 8, 2019, at 01.25 a.m.].

16 Sukardi, Wina Armada. Op.Cit., p. 145. 
is often mentioning the perpetrator's name with the initial and loading a photo with a closed eye pose or only showing a photo of the back of the perpetrator only. ${ }^{17}$

According to researchers, reporting one's name or identity openly in criminal cases nowadays is difficult to avoid. Various media have indeed taken a stand, some have kept their names a secret when they were named suspects and clearly wrote their names when they were accused. There are also media that openly write full names both as suspects and defendants.

The other case is online media (in the network) and television. If the print media keeps the name a secret, the electronic media clearly highlights faces and names clearly. Thus, the print media will be a farce for preaching news which is already known by the public. The inclusion of names is clearly not fully regulated by law except the cases of minors and victims of rape.

For journalists, the most important thing in writing legal news requires an honest and impartial attitude by making the elements of news writing as a standard that must be accomplished before being informed to the public.

Referring to the above thought for fulfilling the element of information verification gives attention to all journalists in order to they are always careful to receive information. Any information which received is not necessarily a source of news but instead checks and rechecks to ensure the credibility of the information. Even after checking and rechecking in the field and proving the truth of the information, it has also not been deemed worthy of reporting because the balanced and judgmental opinions have not been fulfilled in writing the news.

Balanced news writing and 'judging' opinions are two elements that always go together in writing news. Any news that is not balanced, it tends to be 'judging' for the news reported. Vice versa, news that is 'judgmental' tends to produce uneven news. All of these happened because journalists always used their choice of words in news writing, especially the headline, prioritizing the commercial side in order to readers were curious and willing to buy newspapers. The choice of words is legitimate as long as the elements in writing news outlined in the KEJ being implemented.

\section{Conclusion}

Three elements in writing news, testing information, balanced and non-judgmental opinions must be considered by journalists in writing news in order to they are not trapped in violating the presumption of innocence principle. All of these are in adequate if the news are not accompanied by knowledge of the law. Due to journalists often use inappropriate words by perceiving the same language between law and language according to their own thoughts. Every person who becomes a 'suspect' is often perceived as the same as 'perpetrator'. Writing full names without legal status is also often found in news writing, including under-age cases. All of that shows how much legal knowledge for journalists is needed to apply the presumption of innocence on press release.

17 Susanto, Edy, etc. Op.Cit., p. 98. 


\section{References}

Books with an author:

Soemitro, R.H. (1998). Metodologi Penelitian Hukum. Jakarta: Ghalia Indonesia.

Sugiharto, R. Toto. (2019). Panduan Menjadi Jurnalis Profesional. Yogyakarta: Araska.

Sukardi, Wina Armada. (2012). Kajian Tuntas 350 Tanya Jawab UU Pers dan Kode Etik Jurnalistik. Jakarta: Press Council.

Susanto, Edy, Muhammad Taufik Makarao, dan Hamid Syamsuddin. (2014). Hukum Pers di Indonesia. Jakarta: Rineka Cipta.

World Wide Web:

Contoh Berita Tidak Berimbang (Kode Etik Jurnalistik). https://romeltea.com/ [Accessed: August 8, 2019, at 07.05 p.m.].

Makna Cover Both Side Pemberitaan Media Massa di Tahun Politik (A. Yani Surachman). https://www.academia.edu [Accessed: August 5, 2019, at 03.53 a.m.].

Mengenal Prinsip Cover Both Side (Setyo Pamungkas). https://wordpress.com [Accessed: September 9, 2019, at 08.20 p.m.].

Perbedaan Fakta dan Opini. https://www.romelteamedia.com [Accessed: August 8, 2019, at 01.25 a.m.].

\section{Conflict of Interest Statement:}

The author declares that the research was conducted in the absence of any commercial or financial relationships that

could be construed as a potential conflict of interest.

Copyright (C) 2019 ALJ. All rightsreserved. 